\title{
\#workfromhome: how multi-level marketers enact and subvert federal language policy for profit
}

\author{
Sabrina Fluegel ${ }^{1}$ D $\cdot$ Kendall King $^{1}$ (D) \\ Received: 14 August 2020 / Accepted: 1 May 2021 / Published online: 3 July 2021 \\ (C) The Author(s), under exclusive licence to Springer Nature B.V. 2021
}

\begin{abstract}
This paper analyzes how multi-level marketing companies (MLMs), via direct selling through electronic commerce (e-commerce) and social media, enact and evade federal language policy to maximize profits. Here we describe the federal language policies that govern this type of e-commerce, and in particular, the language policies of the Federal Trade Commission, which dictate what can and cannot be communicated by MLM companies and their contractors. We then illustrate how these federal language policies are enacted, and at times subverted, for financial gain during the COVID-19 economic and health crisis which rendered many people vulnerable. We draw on the discourse analysis of public documents, MLM insider sources via the first author, and over 100,000 public Instagram posts published by MLM independent contractors collected with the third-party Instagram data extraction tool, Phantombuster. We find that MLM independent contractors, although varying widely with respect to their enactment of federal and corporate policy, frequently reference COVID-19 implicitly or explicitly, a practice prohibited by federal policy. We demonstrate that quantitative and qualitative discourse analysis of language policies and practices of MLM social media provides a productive lens for understanding both the communication challenges of and responses to the COVID-19 pandemic. This approach reveals the variable ways in which language policies are taken up and discourses recontextualized with new meanings and for new purposes across social media platforms.
\end{abstract}

Keywords COVID-19 $\cdot$ Pandemic $\cdot$ Social media $\cdot$ Hashtags $\cdot$ Instagram $\cdot$ Direct sales $\cdot$ E-commerce $\cdot$ Workplace $\cdot$ \#workfromhome

The authors thank Senior Paid Search Marketing Specialist, Michael Schilling, for facilitating the data collection process for this research via assisting the first author's understanding and navigation of Phantombuster.

Sabrina Fluegel

flueg042@umn.edu

1 University of Minnesota, Minneapolis, USA 


\section{Introduction}

In recent decades, language policy researchers increasingly have taken up tools of discourse analysis to critically examine how language policies are enacted and interpreted (e.g., King \& De Fina, 2010; Martin-Jones, 2015; Wodak \& Savski, 2018). From this vantage point, all policy texts-formal and informal, spoken and written-are understood as social acts, and as products of the particular cultural, political and historical contexts in which they exist (Johnson, 2011). Close analysis of discourses in and around language policy has been productive, for instance, demonstrating how the development and implementation of language policy is deeply intertwined with local cultural norms such as indirectness and conflict-avoidance (King \& Bigelow, 2019). Other work has revealed how test takers and test administrators enact, negotiate and in some instances, undermine, the language policy dictated by federal education law (King \& Bigelow, 2018). These and many other studies demonstrate the benefit of close analysis of discourse in order to better understand how language policies are variably enacted across time and space (Hult, 2010).

Discourse analysis and related ethnographic approaches have been productively applied to a wide range of language policy contexts, including the work setting. Research on language in the workplace has tended to focus on white-collar ${ }^{1}$ language practices (Holmes, 2012), with early studies favoring institutional discourse in predominantly monolingual work environments (Atkinson \& Drew, 1979; Gumperz \& Cook-Cumperz, 1982; Heritage, 1985). More recent work has examined multilingual worksites, although white-collar work still tends to be the general focus (Angouri, 2013; Ehrenreich, 2009; Evans \& Green, 2001; Hill \& Zyl, 2002; Pullin Stark, 2009; Schnurr \& Zayts, 2017; Thurlow, 2020). For instance, research in this area has analyzed discourses of diversity and multilingualism (Angouri, 2013) juxtaposed to actual workplace language practices, uncovering implicit "English only" policies with knowledge of English being necessary for professional advancement (Hill \& Zyl, 2002).

Other, newer work in turn has focused on language policy, planning, and practices in blue-collar workplaces; this research reveals how globalization and intensified transnational interdependencies have created a new economy, altering divisions of labor, including language work, which is being "utilized, conceptualized, practiced and managed in innovative and different ways by both employers and employees in various workplace contexts globally" (Gonçalves, 2020). For instance, research among educated migrant workers on the Faroe Islands uncovered the institutional language policies which shape migrants' experiences, as well as the ways that migrants enact their own language policy decisions and practices in everyday interactions. This work reveals discrepancies between what adult migrants require in

\footnotetext{
1 The term "white collar" is often used to refer to jobs associated with a higher social status and levels of education and contrasts with the term "blue collar" which is often used in reference to working-class labor classified by low status, often physically demanding, sometimes temporary jobs that typically earn hourly wages instead of a salary (Lederer 1979).
} 
terms of language learning needs, on the one hand, and what is available at institutional level, on the other (Holm et al. 2020).

One increasingly salient domain of study is the language policy of online work, and in particular, the language policies that govern the workplaces of electronic commerce (e-commerce) and online marketing. This is in part because with the rise of the so-called 'gig economy' and telecommuting, the traditional physical workspace (i.e., the retail outlet, office cubicle or factory floor) is increasingly obsolete (Katz \& Krueger, 2019). These already-occurring shifts were further accelerated by the COVID-19 pandemic and its subsequent economic fallout, characterized both by decreased formal employment and wide-spread transition to work from home under quarantine and lockdowns. The pandemic also drove dramatic upticks in screen time and social media (up to 30 percent in some regions [Cole, 2020]) and greater public interest in health and well-being (Orendorff, 2020; Rattner, 2020).

This re-shaped social and economic landscape (Rattner, 2020) is ripe terrain for direct sales of health, wellness and beauty products and multi-level marketing (MLM) pitches of business opportunities. This paper critically examines this new type of 'work from home' setting (e.g., online workplace) and analyzes how multi-level marketing companies, via direct selling through e-commerce and social media channels, have enacted and evaded federal language policy for profit. More precisely, we examine how features of discourse such as deictics and (re)entextualization allow consultants to produce texts, and for instance to promote 'work from home' opportunities, in ways which simultaneously comply with federal regulations and subvert them.

As detailed below, (re)entextualization refers to a process whereby texts are moved between spatially and temporally distinct contexts, and thus are subject to transformations in meaning and reference dependent upon the relationships and differences across these contexts (Wodak, 2011). This approach aligns with recent work illustrating that many crucially important social processes can only be understood by moving "beyond single speech events to analyze pathways across linked events" (Wortham \& Reyes, 2015: p. 1). Analysis of contextualization and (re)entextualization, that is, the back-and-forth process through which the relevant context establishes likely interpretations of "the positioning and social action occurring" (Wortham \& Reyes, 2015: p. 38), provides a means for addressing this analytical challenge. Following Silverstein (1992), contextualization refers to the process through which the context relevant to interpreting a particular speech event is established (Wortham \& Reyes, 2015). Over time, speech events become entextualized, "that is, they become stable and identifiable as some kind of social action, after a series of indexical signs has established relevant context and speakers routinely infer that given social action has occurred" (p. 13). Thus, entextualization allows for a stretch of linguistic production-such as 'work from home' or 'in these times'- to be made into a unit, or a "text that can be lifted out of its interactional setting" and used for new purposes and meanings (Bauman \& Briggs, 1990: p. 73).

As evident below, entextualization is a productive conceptual tool for the analysis of how federal language policy is implemented via social media through text and image analysis. This analysis departs from existing research which has tended to narrowly focus on e-commerce information-gathering techniques and ethical concerns 
around online privacy (Farah \& Higby, 2001; Kelly \& Rowland, 2000). Furthermore, most existing work to date has focused on written text via platforms such as Twitter (e.g., Zappavigna, 2012) with scant attention paid to images common on widely used platforms such as Instagram. And more broadly, very little work to date has examined language policy regulation of commercial enterprises and workplaces (e.g., Punti \& King, 2013), especially in the e-commerce domain.

Although many individual states have recognized English as an official language, the U.S. of course does not have an official federal language policy with respect to language status (Ricento, 1996). Nevertheless, numerous federal language policies are in place. By federal, we mean issued by U.S. central government agencies, which have broad, cross-state, nation-wide jurisdiction. Examples of such policies include language education policies regulating support required for English language learners, known at the Lau Remedies (Cassels Johnson et al., 2018) as well as a wide range of federal language guidelines in areas such as aviation, healthcare, and voting (Chen et al., 2007; U.S. Department of Transportation: Federal Aviation Administration, 2017). In addition, as detailed below, several federal agencies monitor and regulate the language used to direct-sell wellness and beauty products via social media.

\section{Federal regulation of wellness and beauty product labeling}

Wellness and beauty items such as face creams, soaps, diet drinks and supplements occupy a 'grey zone' between medical and non-medical products (U.S. FDA, 2018a). While not pharmaceuticals designed to cure disease, these products tend to be marketed as promoting health and well-being. In the U.S., all medical products and drugs must be pre-approved by the Food and Drug Administration (FDA). In contrast, non-medical beauty and cosmetic products do not need pre-approval; however, the FDA has authority to enforce regulations once the product is on the market if the FDA perceives the labeling or promotional claims to be misleading or inaccurate (2018b; U.S. FDA, 2018a). The U.S. Federal Trade Commission (FTC), in turn, monitors the marketing and sales of cosmetics. The FTC is also charged with regulating the practices of multi-level marketing (MLM) businesses, and for instance, as described in the following section, regularly and directly warns consumers that these can be illegal pyramid schemes (FTC, 2019).

In general, policies can be divided into two categories: those that regulate labeling and those that regulate marketing. (Labeling is discussed here; marketing in the section below). The two most important federal laws pertaining to the labeling of cosmetics in the U.S. are the Federal Food, Drug, and Cosmetic Act of 1938 (FD\&C Act) and the Fair Packaging and Labeling Act of 1967 (FP\&L Act 1967). The FDA is tasked with regulating compliance to these laws (FDA 2013). Under the FD\&C Act, the marketing of adulterated or misbranded ${ }^{2}$ cosmetics is prohibited in interstate

\footnotetext{
${ }^{2}$ A cosmetic is considered adulterated if it contains a substance which may be harmful to consumers (U.S. FDA 2018b) and is considered misbranded if its labeling is false, misleading, or fails to reveal material facts (e.g., consequences that may result from product use) (U.S. FDA 2017).
} 
commerce (U.S. FDA, 2018b). The FP\&L Act attempts to ensure that packages and labels provide consumers with accurate information about quantity and contents, and thus facilitate value comparisons by consumers (U.S. FDA, 2018b). The FP\&L Act defines a label as the part that the consumer sees or examines when displayed for retail sale, excluding other printed materials accompanying the product.

'Labeling' thus includes a wide range of descriptive materials that accompany MLM cosmetic products. Accordingly, product information panels must include information such as the name of the product, its identity, net quantity of contents, directions for safe use, warnings, name and place of business, and ingredient declaration (U.S. FDA, 2017). If the FDA has reliable information suggesting that a cosmetic is adulterated or misbranded, they may take regulatory action. For instance, the FDA can pursue action through the Department of Justice in order to remove products in violation of federal law from the market.

\section{Federal regulation of multi-level marketing (MLM)}

In turn, the marketing of these products by MLM businesses is regulated by the FTC Act. This law, known as the FTC Act of 1914, outlaws unfair methods of competition and unfair acts or practices that affect commerce. Under this Act, the FTC is empowered, among other things, to: "(a) prevent unfair methods of competition and unfair or deceptive acts or practices in or affecting commerce; (b) seek monetary redress and other relief for conduct injurious to consumers; (c) prescribe rules defining with specificity acts or practices that are unfair or deceptive, and establishing requirements designed to prevent such acts or practices; (d) gather and compile information and conduct investigations relating to the organization, business, practices, and management of entities engaged in commerce; and (e) make reports and legislative recommendations to Congress and the public" (FTC Act 2006).

Multi-level marketing (MLM), also referred to as direct sales or network marketing, is a business model that, in the words of their trade association, "provides entrepreneurial opportunities to individuals as independent contractors to market and/or sell products and services, typically outside of a fixed retail establishment" (Direct Selling Association, 2020). Within MLM businesses, a contractor's compensation is exclusively based on their level, that is their personal sales and the sales of their own 'downline' recruits. The term 'downline' refers to the network members that a consultant has recruited to their personal team of consultants and are thus a level below them. A 'downline' consultant represents income for an 'upline' consultant as the 'upline' receives a percentage of their recruits' sales. As such, participants are not salaried employees of the MLM business, but independent contractors or distributors, sometimes referred to as consultants or team members.

Popular MLM companies in the U.S. include Amway, Avon, Herbalife, Mary Kay, Tupperware, Nu Skin, and Rodan + Fields. These MLM companies represent a large and growing segment of the retail landscape, earning $\$ 35.2$ billion dollars in sales in 2019 (Direct Selling Association, 2020). In 2019, direct sellers numbered 5.9 million individuals, who reached an estimated 36.9 million consumers. Yet most contractors do not generate significant income and drop out after less than one year, 
often with significant financial losses (FitzPatrick, 2005; Taylor, 2011). According to the Direct Selling Association (2020), the $\$ 35.2$ billion in direct sales (2019)—if divided equally among the 5.9 million sellers - generates an average of $\$ 5,966$ in sales (not income) per seller. Analysis of over 350 MLM companies found that half of all MLM contractors quit within their first year, and $90 \%$ had left the company within five years (Taylor, 2011). Some studies suggest that over $99 \%$ of contractors lose money; other research indicates that $70 \%$ or more earned no income at all (FitzPatrick, 2005; Taylor, 2011).

Approximately three out of four direct sales contractors are women (Direct Selling Association, 2020). MLM companies have long promoted themselves as offering business opportunities that supposedly appeal to women, and mothers of young children in particular, emphasizing the potential to work part-time, with flexible hours and from home. These 'opportunities' might be appealing to women in particular in 2020 as we have been impacted disproportionately by the pandemic economic downturn given women's relatively higher rates of employment in retail and hospitality sectors; simultaneously, women are more likely to engage in unpaid activities within the online economy (Cole, 2020). Multi-level marketing has leaned into these trends, often taking up cute, 'feminist-light' slogans and hashtags such as 'bossbabe', 'beyourownboss', 'ladypreneur', and 'CEOmom' (Asymkos, 2020). While often promoted as women-friendly businesses focused on selling products that appeal to women, MLMs have been critiqued for encouraging the exploitation of female family and friendship networks (Richards, 2019; Tiffany, 2020).

MLMs have also been described (and in some cases, charged by the FTC) as functioning as illegal pyramid schemes in instances in which contractors' earnings are based not on their own product sales, but the recruitment of new distributors or contractors ('downline'), often via unrealistic claims about earnings. For instance, in October of 2019, the FTC announced a case against the MLM skincare and wellness company, AdvoCare International, to cease operations of an alleged pyramid scheme and to return money to consumers. The company settled and agreed to pay $\$ 150$ million to consumers and was subsequently banned (Gressin, 2019). To date, every MLM case filed by the FTC has alleged misleading claims about financial opportunities for contractors (Gressin, 2019). Pyramid schemes are fraudulent, but often seem to operate much like lawful MLMs (South Dakota Consumer Protection, 2020). The (thin, grey) line differentiating an unlawful pyramid scheme and a lawful MLM is that MLMs generate income by selling a commercial product such as lotion; in turn, pyramid schemes make money by enticing and enrolling new participants, who pay to join and/or pay for training and/or educational materials (South Dakota Consumer Protection, 2020). While MLMs are legal in the U.S. and typically make efforts to distinguish their companies from illegal pyramid schemes, whether the two are actually different is a topic of perennial debate (Partnoy, 2014; Tiffany, 2020).

In the past, MLM direct sales were conducted primarily via face-to-face encounters and social events (e.g., Tupperware or Avon parties). Over the last decade, this work is increasingly conducted via social media, in particular Facebook, Instagram and Pinterest (MLMs are banned on TikTok). Today, successful MLM contractors maintain a robust presence on social media, often with thousands of 'friends' or 
'followers' and myriad public and private 'groups', 'events' and 'stories'. Many contractors integrate the promotion of MLM products and businesses into their personal pages and posts, blurring the lines across personal domains and the workplace. As suggested above, the COVID-19 pandemic intensified this shift towards online sales as millions of people limited in-person contacts and turned to online sites for information, entertainment, income-generation and commerce (Rattner, 2020). Online sales of beauty and personal care products in the U.S., for example, increased by 38-53\% during the Spring 2020 quarantine (Orendorff, 2020; Rattner, 2020).

As evident above, marketing, communication and social media presence are central to MLM businesses. Federal agencies (in particular, the FTC) regulate via language policies what can and cannot be communicated by MLM contractors. MLM companies, in turn, can issue general directives to contractors, but compliance mechanisms tend to be diffuse. Contractors, for their part, are not employees of MLM companies, nor entirely independent entrepreneurs. They are subject to FTC regulations, but have broad latitude in how they interpret these language policies as they sell products and market the business of selling.

This paper examines the language policies that frame these practices with an emphasis of how these policies have been enacted at these different levels in light of the COVID-19 pandemic of 2020. By focusing on the language policies and practices of one MLM company, we take up three research questions:

(1) What federal language policies regulate the marketing of wellness or cosmetic products?

(2) How do MLM companies implement these language policies?

(3) How do individual contractors enact these language policies?

\section{Methods}

To address these questions, we closely examined a range of texts, focusing in particular on how discourses are taken up and (re)entextualized in the marketing of MLM products and business 'opportunities' during the pandemic. In doing so, we illustrate how varied discursive resources such as deictics, pronouns, and recontextualization in particular, allow consultants to produce particular types of texts which, on the one hand, comply with federal regulations and corporate mandates and, on the other, subvert them. Below we first describe the context of our study, including details about the MLM we examined: Rodan + Fields. We note our own positionalities, including the first author's role as a Rodan + Fields consultant, and then explain what data we collected and how we analyzed these texts quantitatively and qualitatively.

\section{Rodan + Fields}

To allow for close analysis of how language policies are variably enacted in one site, we focused on one particular MLM company, Rodan + Fields $(\mathrm{R}+\mathrm{F})$. According to 
$\mathrm{R}+\mathrm{F}$ 's website, the company's "life-changing skincare and business model" have received praise from Beauty Editors, Influencers and business reporters across the country. The company was named the \#1 skincare brand in North America in 2019 by the global market research company, Euromonitor International (Rodan + Fields 2021a). R+F contractors are known as "Independent Consultants"-who the company claims to "empower to become entrepreneurs" (Rodan + Fields 2021b).

According to their Consultant Policies and Procedures, at the time this research was conducted (2020a), to become a U.S. Consultant, one must be 18 years old, submit a Consultant Application, be authorized to run a business, and have an address to which products can be sent. Once approved, individuals must purchase a "Business Building Kit” (ranging in price from \$45 to \$995). The basic business kit (\$45) contains information about the company, but no products (Rodan +Fields 2020b). More expensive kits, in turn, include full-sized $\mathrm{R}+\mathrm{F}$ products and "multiple shareable tools to help you to immediately begin prospecting Customers and Consultants" (Rodan + Fields 2017). These tools include samples for enrollment incentives, printed materials such as the First Steps Business Guide, Product Guide, and the company's "Before and Afters" flip book (Rodan + Fields 2020b).

New consultants can then begin "building their business" through product sales on their personalized $\mathrm{R}+\mathrm{F}$ websites. $\mathrm{R}+\mathrm{F}$ Consultants are responsible for generating new customer accounts, implementing networking and content marketing strategies, planning strategic brand-building events, participating in client relationshipbuilding activities (e.g., hosting Zoom events, product webinars, product giveaways), and answering customer questions regarding products. $\mathrm{R}+\mathrm{F}$ Consultants often use social media platforms to promote their sales, posting about the products and "business opportunities" on platforms such as Facebook and Instagram.

$\mathrm{R}+\mathrm{F}$ Consultants vary in their engagement in these activities; however, few earn anything close to a livable wage or a "life-changing" salary. According to R+F's 2019 Income Disclosure Statement, only 55\% of its 362,300 consultants were paid a commission in at least one month for sales that occurred during 2019. Of those who earned compensation, $67.1 \%$ earned less than $\$ 1000$ annually, and $32.9 \%$ earned over $\$ 1000$ (with $24.6 \%$ of those consultants earning between $\$ 1000$ and $\$ 5000$ annually). Put differently, only $8.3 \%$ of $\mathrm{R}+\mathrm{F}$ consultants earned more than $\$ 5000$ in income from $\mathrm{R}+\mathrm{F}$ sales in 2019. Although consultants earn commission on personal sales, the more they grow their downline team, the greater their total paycheck. Within $\mathrm{R}+\mathrm{F}$, consultants are designated titles based on their 'Levels', ranging from Level 1 to Level 5, and 'Executive Consultant', depending on monthly sales volume and number of downline consultants.

\section{Positionalities}

The first author has been an avid consumer of $\mathrm{R}+\mathrm{F}$ products for over four years and worked as a consultant for three of those years. In that capacity, she has significant experience with creating policy-compliant content for social media marketing campaigns. As a consultant, she has access to corporate emails, consultant-only websites (e.g., the company's proprietary 'library' containing archived policy documents), 
consultant-only rewards programs, training materials (images, videos, and written manuals) about $\mathrm{R}+\mathrm{F}$ business and products, and corporate-created marketing materials. She also has exclusive access to private social media groups created by upline consultants for coaching and recruiting purposes. The second author, in turn, has purchased and used $\mathrm{R}+\mathrm{F}$ products, and has also written critically about MLM companies such as Herbalife and Amway (Punti \& King, 2013).

\section{Data sources}

To address the first research question concerning federal language policies, we closely examined federal laws related to cosmetics marketed in the U.S., including the Federal Food, Drug, and Cosmetic Act (FD\&C Act) and the Fair Packaging and Labeling Act (FP\&L Act 1967). As noted above, skincare, while often promoted as a quasi-medicinal, dermatologist-created product, is regulated as cosmetics (U.S. Food \& Drug Administration, 2018b). We focused on close analysis of federal regulating documents, including the Federal Trade Commission Act, the FDA's Cosmetic Labeling Regulations and a recent 2020 COVID-19 warning letter from the FTC to $\mathrm{R}+\mathrm{F}$.

To address the second question regarding how MLM companies enact these language policies, we reviewed $\mathrm{R}+\mathrm{F}$ 's corporate communications, including direct emails sent to $\mathrm{R}+\mathrm{F}$ 's consultants just prior to and during the pandemic as well as existing corporate policy and procedures documents. These texts were obtained through search of public FTC communications, and through the first author's position as an $\mathrm{R}+\mathrm{F}$ consultant.

To address the third research question concerning how individual contractors enact and subvert these language policies, we collected Instagram posts containing the hashtag \#rodanandfields using the third-party data collection tool, Phantombuster, discussed in our analysis below. We then identified those posted over a 20-day period: 10 days prior and 10 days following a major $\mathrm{R}+\mathrm{F}$ policy compliance communication was sent. We then searched this timeframe pool using additional terms and hashtags to identify posts which contained compliant and non-compliant words and discourses according to the FTC and R+F. Additionally, the first author's insider access to consultant-only Facebook groups allowed us to collect livestream videos and graphics posted by consultants to train 'downline' consultants in language use practices for product sales during quarantine.

\section{Analysis}

Analysis of the language policies and practices of MLM social media provides us with a productive lens for analyzing the variable ways in which language policies are taken up. To do this work, we engaged in qualitative analysis of how discourses were recontextualized with new meanings across social media platforms. We also conducted quantitative analysis to assess FTC compliance across thousands of posts. This layered, mixed-methodological approach allowed us to make claims about the levels and 
frequency of compliance across the company, but also to uncover the particular discursive strategies at work (King \& Mackey, 2016). These distinct but complementary approaches are described below.

\section{Quantitative analysis}

In contemporary search engines, image-retrieval uses a text-based approach, relying on specific keywords or descriptions to yield results (Giannoulakis \& Tsapatsoulis, 2016). We identified keyword descriptors via hashtags, that is single or multiple words preceded with '\#'. Authors of social media posts generally use the hashtag symbol to indicate relevant content, categorizing the post to make it readily identifiable in searches (2016). For our analysis, we used the third-party Instagram data extraction tool, Phantombuster, which utilizes Instagram's API (Application Programming Interface) to collect data. Simply put, APIs make it possible for different apps to 'talk' to each other. Using APIs, Phantombuster is able to connect to Instagram to scrape the social media app for publicly available data, such as specific hashtags. We used Phantombuster to scrape public Instagram posts for the hashtag '\#rodanandfields.' Of the over 2 million posts on Instagram that contained \#rodanandfields at the time of data collection, Phantombuster was able to collect data from 100,331 posts. We narrowed these posts down to the timeline of investigation for our study, collecting and analyzing 5270 Instagram posts containing '\#rodanandfields' published between April 14, 2020 and April 24, 2020, and 5460 posts published between April 26, 2020 and May 6, 2020, ten days leading up to and following the COVID-19 compliance letter from $\mathrm{R}+\mathrm{F}$ to consultants.

We then searched the posts for words or phrases that either the FTC or R+F had expressly prohibited as both words and hashtags. These FTC or R+F-prohibited and non-compliant words included: coronavirus, COVID19, quarantine, shutdown, socialdistancing, shelterinplace, pandemic, epidemic, unemployment, recession, uncertaintimes, financialfreedom, residualincome, timefreedom, careerlevelincome, debtfree, passiveincome, retired, retiredmyspouse, millionairemom, and sitbackandearncash. We then searched for use of other COVID-19-related terms, phrases and hashtags in order to analyze how consultants were invoking COVID-19 implicitly. These included terms such as Plan B, stimulus check, work from home, times like these, and right now.

Our quantitative analysis examined the relative frequency of compliant and noncompliant hashtags and terms before and after the FTC warning letter discussed below. We used results of the searches described above to determine the extent to which COVID-19-related and other non-compliant hashtags were used by consultants and how this varied prior to and following compliance directives from $\mathrm{R}+\mathrm{F}$ corporate offices.

\section{Qualitative analysis}

We also qualitatively examined the imagery and language in consultants' posts. ${ }^{3}$ In particular, we analyzed how certain features of text, when paired with particular

\footnotetext{
${ }^{3}$ Screenshots of social media texts were altered with photo-editing software to remove identifying information in order to respect consultants' privacy (e.g., blurred faces and tattoos).
} 
images, allowed consultants to comply with federal regulations and corporate mandates and simultaneously subvert them by invoking the social and economic context of COVID-19. This included close analysis of deictics, words with fixed semantic meaning but variable denotation depending on context. Deictic words or phrases, such as 'we', 'right now' or 'these times', require co-text, context—or contextualization cues (Gumperz, 1992) in the form of additional text, hashtags, or images- to take on their full meaning or reference.

This work also demanded examination of how discourses move across time and space via entextualization. Analysis of entextualization allows for this by emphasizing the ways that discourse can be detached from its original situational context and then recontextualized in new sites of discourse for new meanings (Androutsopoulos, 2014). In this sense, entextualization involves two related processes: decontextualization, taking discourse material out of its context, and recontextualization, integrating and modifying this text so that it fits in a new context and creates new meanings. Analysis of entextualization involves examining the means and mechanisms available to participants to render stretches of discourse into coherent and effective texts. As Bauman and Briggs (1990) argued, creators of these new texts are active agents for whom entextualization is "an act of control" (p. 76), enabling a degree of social power.

Recent work applies analysis of entextualization to social networking practices, expanding our understanding of entextualization in at least two ways (Androutsopoulos, 2014). First, entextualization across social networking includes not only what is said, but also what is represented, through the semiotic resources that social networking sites afford participants. Current work must consider the affordances of contemporary "technologies of entextualization" (Jones, 2009), and their appropriation by individuals or groups (Androutsopoulos, 2014). Hashtags are a particular technology of entextualization; they have linguistic metafunctions (Wikström, 2014; Zappavinga, 2015) that work to construe experience (e.g., labeling content), to enact relationships (e.g., indicating evaluative stance), and/or to organize text (e.g., marking metadiscourse with '\#” as in “\#workfromhome”) (Zappavigna, 2015: p. 288).

The second important aspect of entextualization is its participatory character. In contrast to traditional top-down institutional discourse, social media offers easy access to the means of participatory entextualization via sharing, reposting, authoring and commenting on mass-mediated social platforms (Rymes, 2012). Here we take up close analysis of how language is regulated and how discourse-via processes of entextualization and other processes-move across time and space to evoke new meanings.

\section{Findings}

Below we overview the federal language policies that regulate the marketing of wellness or cosmetic products, how MLM companies enforce these language policies, and how individual contractors enact these same language policies. Overall, findings suggest that the tiered structure of MLM companies, together with affordances of social media, permits independent contractors to evade federal language policy 
and company-level language regulations. More precisely, this multi-level structure allows the corporate office to issue broad directives that emphasize compliance with the federal language policy in ways that minimize their legal and financial risks. Concomitantly, contractors largely remain free to evoke COVID-19, to use prohibited language, and to evade these federal language policies without repercussions. As illustrated here, deictic reference and entextualization, in conjunction with the imagery of social media, largely enable this evasion of federal language policy.

\section{Federal language policies regulating the marketing of cosmetics}

As noted above, two federal agencies regulate the sale and marketing of cosmetics in the U.S.: the FDA and the FTC. Because wellness and beauty products occupy a grey space between medical and non-medical products, the policies that regulate these products are numerous and vast (2018b; U.S. Food \& Drug Administration, 2018a). Regulation of language, that is language policy, is a central component of much of this legislation. The FDA and FTC's policies govern the language of the claims made in the marketing of MLM products and businesses to consumers. The FDA and FTC stipulate both what can be said, and how it can be said. This language policy regulation is evident in the FTC's campaign, initiated in March 2020, to protect consumers from the growing number of COVID-19-related scams (FTC, 2020). Campaign efforts to date include issuing guides for consumers and businesses to identify and avoid scams; tracking COVID-19-related complaints by state; and issuing cease-and-desist warning letters to businesses marketing unsubstantiated COVID-19 treatments or preventatives (FTC, 2020).

As part of this effort, on April 24, 2020, the FTC sent warning letters to 10 MLM companies, including Rodan + Fields (see Appendix 1 for full text). These FTC letters warned companies to cease claims about treating or preventing COVID-19 and to stop using pandemic references to promote business opportunities. These were the first FTC warnings concerning pandemic-related marketing claims of potential earnings. The FTC charged that these false or misleading earnings claims were a violation of federal law, Section 5 of the FTC Act, 15 U.S.C. $\$ 41$ et seq.

The FTC letter to R+F (Appendix 1) lists examples of social media posts by consultants containing claims about potential income. Notable here is that while the FTC letter refers to general regulations about earnings claims, all of the examples of violations cited here refer to the COVID-19 context. These range from specific, explicit references as in the first example ("always open for business even during the quarantine!") to more subtle, indirect references to COVID-19 ("when Plan A crumbles" or "an uncertain time like this"). In these latter cases, the FTC suggests that the authors have utilized common, non-specific phrases ("time like this") to invoke COVID-19. The FTC letter does not explicitly state that situating promotional claims within a COVID-19 context is a violation of policy; however, all of example violations do exactly that, suggesting that this is the trigger for the warning letter from the FTC COVID-19 Task Force.

The FTC letter to $\mathrm{R}+\mathrm{F}$, like those issued to other MLM companies, gave them $48 \mathrm{~h}$ to respond to the FTC with explanations of how they planned to correct these 
legal violations. The FTC letters do not make clear what consequences companies would face for noncompliance. However, $\mathrm{R}+\mathrm{F}$ is directed to mandate its participants to stop making claims about "false, mis-leading or unsubstantiated" representations about income, and to monitor participants' compliance.

Below we highlight how $\mathrm{R}+\mathrm{F}$ implemented the federal directives and how independent consultants variably did so. We demonstrate how the tiered structure and incentive system of MLM companies, the financial and social fallout from COVID19 , and the ways entextualization functions to create new meanings together allow MLM companies to exploit the present situation for profit and with impunity. We start by reviewing company implementation of federal language policy and then turn to the varied responses by consultants.

\section{Company implementation of federal language policy directives}

Review of corporate-to-consultant communication in the two years leading up to the FTC's letter reveals that updates on policies and procedures were routinely sent via company-wide email, following $\mathrm{R}+\mathrm{F}$ 's policy that "notice of any substantive changes will be provided to consultants via email" and insider channels such as the consultant-only library (Rodan + Fields 2020a). Such emails noted, for instance, that "Rodan + Fields is making upcoming revisions to the Policies and Procedures (P\&Ps), effective as of April 1, 2020. It is your responsibility to be familiar and comply with these Policies and Procedures" (Rodan + Fields \& personal communication, 2020). These emails contained highlighted sections of the modified policy text. In the first author's experience, prior to April 25, 2020, no direct correspondence from the company listed words or phrases to avoid.

However, in an apparent response to the FTC letter, just one day following the release of the FTC letter, on April 25, 2020, R+F sent a mass email communication to all consultants (see Appendix 2 for full text). The email stated that certain words were prohibited in all sales communications. In contrast to the FTC letter, which focused on earnings claims and made no explicit mention of terminology nor of violations with respect to COVID-19 language (except through the listing of problematic examples), $\mathrm{R}+\mathrm{F}$ directly warned consultants that they should avoid "linking challenges created by the COVID-19 pandemic and/or economic situation in any way to the $\mathrm{R}+\mathrm{F}$ business opportunity."

The $\mathrm{R}+\mathrm{F}$ letter is far more specific than the FTC letter in that it provides single examples of non-compliant words, phrases and hashtags. Some examples are clearly related to the pandemic (e.g., 'shutdown', 'social distancing', '\#shelterinplace'); others are less overtly pandemic-related (e.g., 'unemployment', 'uncertain times', '\#millionairemom'). These $\mathrm{R}+\mathrm{F}$ compliance directives were also more specific than what is prescribed in R+F's Policies and Procedures (2020a) at the time letter was sent, which, in reference to specific language use, only states that consultants must "avoid inappropriate conversations, comments, images, video, audio, applications or any other adult, profane, discriminatory or vulgar content" (Rodan + Fields, 2020a).

Company policies, however, do prohibit disclosing income information. According to $\mathrm{R}+\mathrm{F}$ 's policies, if a consultant makes a statement about earnings, the 
information must be "accurate and not misleading, where misleading can be considered anything not typical" (2020a). Additionally, the consultant must detail the level of effort necessary to achieve the results described; only provide typical income examples that are clearly indicated as hypothetical; not disclose their actual earnings; and provide the Income Disclosure Statement document (directly or via link), "This is my unique story; for info re: typical earnings click here" (Rodan + Fields, 2020a), in any and all communications that include lifestyle claims. This is likely because, according to FTC regulations, if independent contractors note income (for instance, by alluding to a new car purchased with MLM earnings), they also must disclose average earnings of all contractors in adherence to federal truth-in-advertising laws (Gressin, 2020).

The April $2020 \mathrm{R}+\mathrm{F}$ letter to consultants concludes with the statement: "Thank you in advance for avoiding any future improper claims of earnings or earning potential. We appreciate your partnership and efforts in protecting your $\mathrm{R}+\mathrm{F}$ business." This final sentence emphasizes the independence and responsibility of contractors through use of the phrases 'your partnership' (reiterating that consultants are not employees but contractors) and 'your R $+\mathrm{F}$ business'. Use of the possessive 'your' suggests that the consultant (not $\mathrm{R}+\mathrm{F}$ ) is liable for the consequences that result from improper claims. Consequences include "removal of non-compliant or infringing posts from any Consultants' social media pages" (Rodan + Fields 2020a) and potential termination of a consultant who "materially or repeatedly breaches" the $\mathrm{R}+\mathrm{F}$ ethical and legal compliance policies.

As evident below, independent contractors have considerable latitude in interpreting these language policies and FTC regulations. While companies like $\mathrm{R}+\mathrm{F}$ can issue statements such as this which emphasize compliance, enforcement mechanisms are unclear, and as detailed below, consultants can flagrantly violate or subvert these mandates with apparent impunity.

\section{Independent consultant uptake and implementation of language policy}

$\mathrm{R}+\mathrm{F}$ consultants, like many business owners, shifted marketing strategies in light of COVID-19. Some of these entail innocuous adjustments. For instance, $\mathrm{R}+\mathrm{F}$ corporate began referring to what they previously called "travel regimens" as "mini regimens" due to reduced travel-related sales (Radford et al., 2020). In private FB pages created by consultants for their downline teams, consultants encouraged the use of the name "mini regimens" for sales promotion. Likewise, and as evident below, we found that some consultants mirrored corporate's message around language in their own private training groups. However, analysis also suggests that even after the warning letter, $\mathrm{R}+\mathrm{F}$ contractors referenced COVID-19 contexts, either implicitly or explicitly. Below we describe these varied responses in both qualitative and quantitative terms. We first show that many consultants complied with the corporate message, then how consultants flagrantly violated it, and lastly how some evaded it via sophisticated use of text and imagery. Throughout the various examples below, language referencing the COVID-19 context is bolded, and collective plural pronouns ('we' and 'us') are underlined. 


\section{Compliance: reiterating and reinforcing corporate message}

Review of 11,523 Instagram posts and monitoring of private, consultant-only Facebook groups between April 24, 2020 and May 6, 2020 suggests that many consultants reiterated and reinforced the corporate message. In some instances, consultants copied the message from $\mathrm{R}+\mathrm{F}$ corporate and pasted it into their own team Facebook pages with an additional personal message such as "Super important-read this YOUR BUSINESS DEPENDS ON IT" and instructed consultants to comment when the policy had been read, to tag their team members to spread the message, and to make changes to posts or hashtags if necessary (private Facebook group, April 25, 2020). In other groups, upline team leaders hosted compliance training sessions. For instance, as evident below (Figure 1), one consultant encouraged her downline consultants in a private, consultant-only Facebook group to attend a compliance training, and notes, "If you don't have anything compliant to say, don't say it at all..." (line 4). She stressed the importance of knowing "the compliant way to talk the talk" (5).

Notable here is the 'light touch' of this invitation. For instance, team members are positioned as (potentially) unintentionally using non-compliant language (line 7: "you didn't even realize"). Team-members are told they will be provided "some alternative language options" (8) at this session which is not "mandatory or required" (10). Concomitantly, this consultant-like R+F corporate-stresses the importance of participation in order to protect "your business" (5-6; 9), emphasizing that legal liability rests with individual consultants.

Quantitative analysis of the relative frequency of prohibited words and hashtags in Instagram posts suggests that consultants reduced their use of non-compliant words and hashtags following the $\mathrm{R}+\mathrm{F}$ April 24 letter (Table 1). For instance, ten days prior to the $\mathrm{R}+\mathrm{F}$ compliance letter, there were 632 posts using the word 'quarantine' and 356 with '\#quarantine'; ten days following the letter, these numbers had dropped to 235 and 115 respectively.

\footnotetext{
1 Please read - I HIGHLY recommend each one of you be on one of the two calls! Let me know

2 which one you will be on!

3 From Myisha Proctor and will be VERY HELPFUL information!!

4 If you don't have anything compliant to say, don't say it at all...

5 Knowing the compliant way to talk the talk is very important when it comes to protecting your

6 business. There may be something you have been taught, somethings you have been doing for a

7 while and somethings you didn't even realize were all non-compliant. Join me for a training as I

8 walk you through it all and provide some alternative language options to help you continue to

9 share your business and products compliantly and with passion.

10 We do not want to say this is mandatory or required but it is highly recommended that you

11 attempt to join and encourage your team to if the timing fits or listen to the recording once

12 available to you and share with your teams.
}

Fig. $1 \mathrm{R}+\mathrm{F}$ independent consultant communication to team of consultants in private Facebook group (April 28, 2020) 
Table 1 Consultant Instagram posts containing words and hashtags listed as non-compliant in $\mathrm{R}+\mathrm{F}$ corporate communication to consultants prior and after $\mathrm{R}+\mathrm{F}$ letter (April 25, 2020) (The non-compliant words and hashtags 'epidemic', 'retired my spouse', 'millionaire mom', and 'sit back and earn cash' provided in the $\mathrm{R}+\mathrm{F}$ letter (see Appendix 2) returned 0 search results.)

\begin{tabular}{|c|c|c|c|}
\hline Word hashtag & $\begin{array}{l}\text { Number of occurrences ten } \\
\text { days prior to } R+F \text { letter (out of } \\
5392 \text { posts) }\end{array}$ & $\begin{array}{l}\text { Number of occurrences ten } \\
\text { days following } R+F \text { letter (out } \\
\text { of } 6131 \text { posts) }\end{array}$ & $\begin{array}{l}\text { Change in } \\
\text { number of } \\
\text { occurrences }\end{array}$ \\
\hline Coronavirus & 26 & 12 & -14 \\
\hline \#coronavirus & 14 & 7 & -7 \\
\hline COVID - 19, COVID & 55,176 & 23,72 & $-32,-104$ \\
\hline \#covid19, \#covid & 2,97 & 0,36 & $-2,-61$ \\
\hline Quarantine & 632 & 235 & -397 \\
\hline \#quarantine & 356 & 115 & -241 \\
\hline Shutdown & 5 & 0 & -5 \\
\hline \#shutdown & 1 & 0 & -1 \\
\hline Social distancing & 41 & 16 & -25 \\
\hline \#socialdistancing & 39 & 51 & +12 \\
\hline Shelter in place & 13 & 2 & -11 \\
\hline \#shelterinplace & 7 & 3 & -4 \\
\hline Pandemic & 79 & 26 & -53 \\
\hline \#pandemic & 18 & 2 & -16 \\
\hline Unemployment & 23 & 3 & -20 \\
\hline \#unemployment & 3 & 0 & -3 \\
\hline Recession & 44 & 11 & -33 \\
\hline \#recession & 6 & 3 & -3 \\
\hline Uncertain times & 25 & 11 & -11 \\
\hline \#uncertaintimes & 0 & 0 & 0 \\
\hline Financial freedom & 9 & 2 & -7 \\
\hline \#financialfreedom & 6 & 6 & -6 \\
\hline Residual income & 35 & 11 & -24 \\
\hline \#residualincome & 74 & 15 & -59 \\
\hline Time freedom & 4 & 6 & +2 \\
\hline \#timefreedom & 15 & 6 & -9 \\
\hline Debt free & 1 & 2 & +1 \\
\hline \#debtfree & 6 & 1 & -5 \\
\hline Passive income & 0 & 1 & +1 \\
\hline \#passiveincome & 6 & 7 & +1 \\
\hline Retired & 7 & 4 & -3 \\
\hline \#retired & 2 & 0 & -2 \\
\hline Total & 1827 & 675 & -1222 \\
\hline
\end{tabular}

${ }^{a}$ COVID' was not listed in the $\mathrm{R}+\mathrm{F}$ letter but is a variation of the prohibited term 'COVID-19' that was widely used in consultants' Instagram posts 
Overall, there was a reduction in direct references to COVID-19, with $34 \%$ of posts using these terms prior to the FTC letter, and $11 \%$ ten days following. Some consultants continued to use these non-compliant terms. We turn next to these flagrant, overt violations.

\section{Rejection: flagrant violations}

As evident in Table 1, some consultants apparently ignored or rejected $\mathrm{R}+\mathrm{F}$ corporate directives and continued to promote $\mathrm{R}+\mathrm{F}$ using explicit COVID-19 language, such as 'recession-proof industry', 'pandemic', and '\#quarantine'. These posts make direct or indirect connections between $\mathrm{R}+\mathrm{F}$ business opportunities and the pandemic. These are considered flagrant because they use words expressly prohibited by $\mathrm{R}+\mathrm{F}$ and were flagged (via examples) as non-compliant by the FTC.

For instance, Figure 2 is the caption from a consultant's Instagram post (consultant's selfie omitted for privacy purposes) containing words expressly prohibited in the $\mathrm{R}+\mathrm{F}$ letter. These include 'pandemic' and 'uncertain' (line 1) as well as '\#residualincome' (9). The consultant references the 2008 economic crisis as a time in which the company thrived despite the economic downturn. The Instagram post appeared after the FTC and R + F compliance warning letters and makes direct, explicit connections between the global pandemic and $\mathrm{R}+\mathrm{F}$ business opportunities. The $\mathrm{R}+\mathrm{F}$ consultant's use of terms and language overtly linked to COVID-19 suggests she was either unaware of or chose to disregard $\mathrm{R}+\mathrm{F}$ corporate directives. Also notable is her use of the hashtags 'workfromhome' and 'workfromanywhere'

\footnotetext{
1 During this pandemic, it's a time of great uncertainty and many are looking for additional ways to

2 bring in an income. Rodan +Fields started in 2008 when the economy crashed and their business

3 boomed! They built a billion dollar brand in 8 years, are only in three countries, soon to be four (-).

4 Apple hit a billion dollars in 6 years and they are worldwide, if that gives you any perspective. This

5 opportunity is real. It blessed lives! It has blessed my life! So, to anyone out there that has

6 questions... I'm here. Never any pressure, just info. You'll know if it's for you

7 \#workfromhome

8 \#workfromanywhere

9 \#residualincome \#beyourownboss
}

Fig. 2 Caption from Instagram post by R+F independent consultant (April 29, 2020) 
(7-8). While 'work from home' was promoted pre-pandemic on social media by MLM contractors as a cushy employment perk, in the context of a pandemic, the phrase tends to reference any income-generating work that can be done in safety-or at all.

\section{Working around: technical compliance and evasion of corporate guidelines}

While some consultants promote the $\mathrm{R}+\mathrm{F}$ and FTC guidelines and others flagrantly violate them, we found that an additional group of consultants take a middle path, using contextualization cues (Gumperz, 1982) to evoke COVID-19, and thus evade federal and corporate directives. These consultants do not explicitly mention COVID-19, but instead use words, phrases and hashtags such as 'right now', 'times like these', 'unpredictable', or 'side hustle' which—often in conjunction with imagery or other discourse-invoke the pandemic.

For instance, Figures 3 and 4 (below) illustrate how consultants use the deictic phrase 'right now' to these ends (line $1 ; 2$ ). This temporal deictic reference situates the speaker/writer in a particular time (in this case, in the pandemic present), and as with all deictics, meaning is dependent upon the context provided or created by the speaker/writer and the listener/reader. The author of the Figure 3 post invokes a COVID-19 temporal context with the images and words on the left. The laptop, plant and mug suggest a cozy, at-home work environment. The superimposed text and image to the left provide a 'headline' and supposedly authoritative claim to be taken up in her more personal commentary post to the right: "Need an extra income right now?' (1). The 'right now' (line 1; right panel) refers to a temporal pandemic 'now' when "many Americans need income" (left panel).

The author of Figure 4, below, takes a similar approach to situate the reader in a pandemic context with the same simple text, this time with a pink background. The commentary and personal text on the right elaborates with a more personal message: "Here's a list of things selling at an all time high right now //-toilet paper, puzzles, nail kits and ... SKINCARE!" (lines 1-3). The reference to 'toilet paper' further emphasizes the deictic temporal reference ("right now") to a quarantine "now' context given extensive media coverage of shortages and panic-buying of toilet paper in the U.S. and elsewhere in March 2020.

The identical text to the left in both Figures 3 and 4 was promoted by upline consultants. Our review of $\mathrm{R}+\mathrm{F}$ consultant-only Facebook groups indicated that team leaders of consultant-only Facebook pages circulated an article, " Some people 


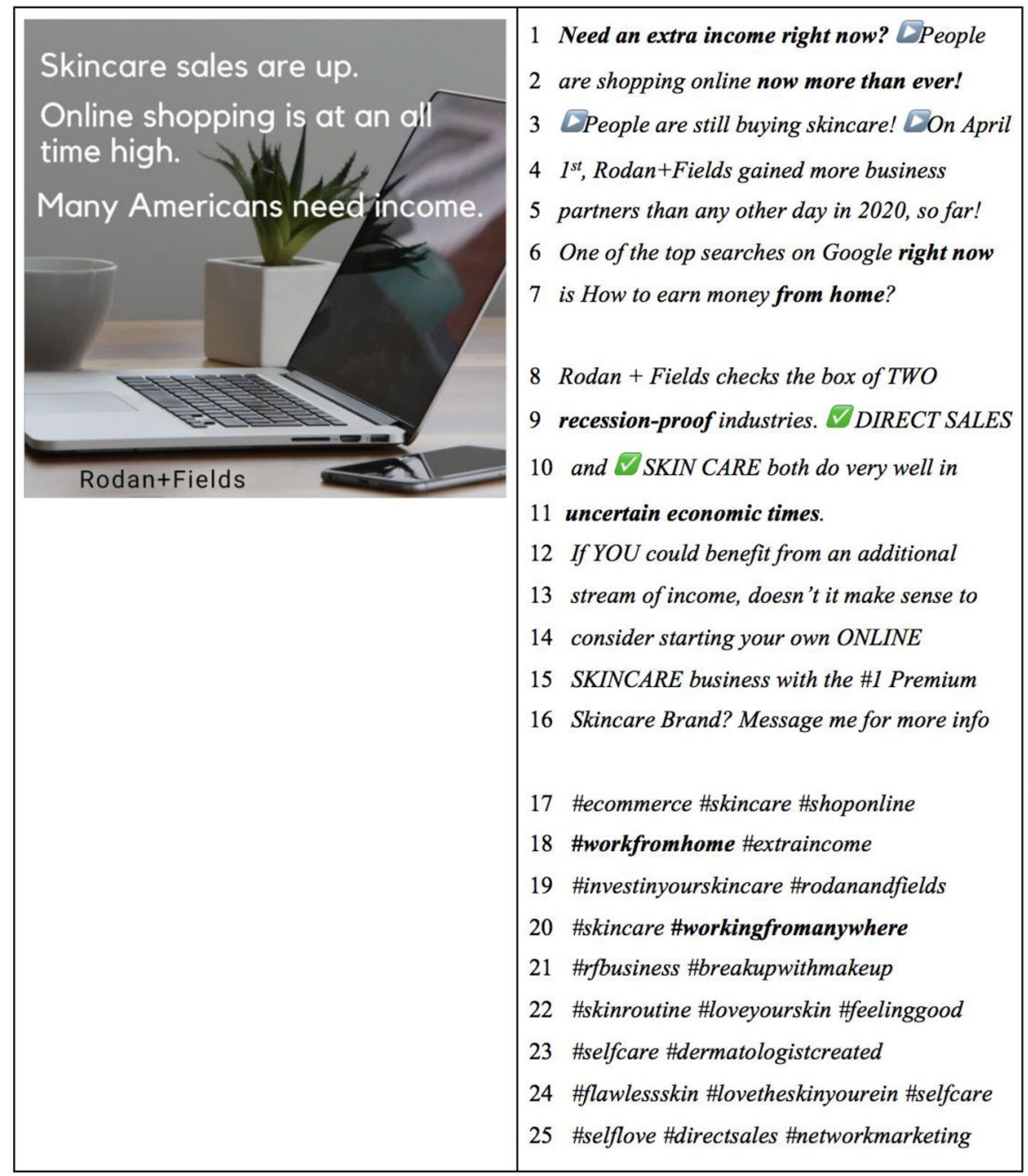

Fig. 3 Instagram post by Rodan + Fields independent consultant (April 29, 2020) 


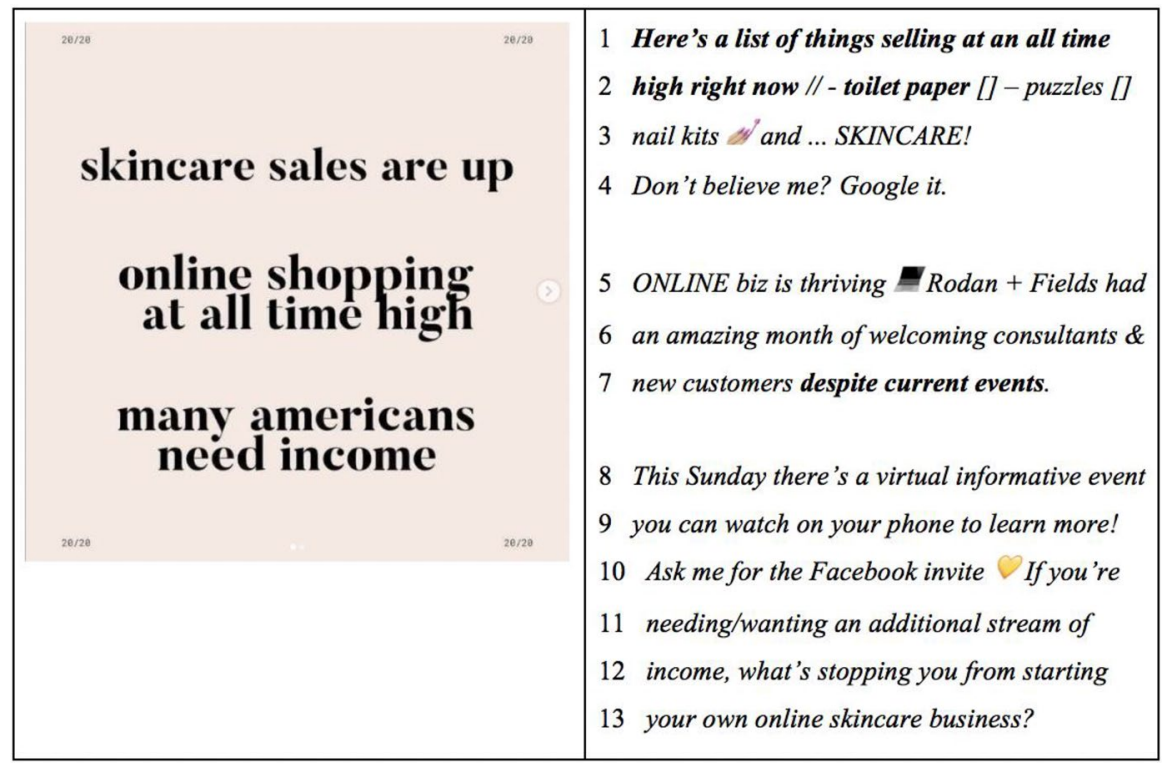

Fig. 4 Instagram post by $\mathrm{R}+\mathrm{F}$ independent consultant (April 25, 2020)

got toilet paper, I got hyaluronic acid': Skin-care panic buying is real". The article stated that among the categories of products Americans planned to stock up on during coronavirus, skincare rated third (Flora, 2020). Resources such as this are often shared by upline consultants to encourage downlines to share them to grow their businesses, recruit members, and help recruits to promote their sales. Lower-level consultants, such as those featured in Figures 3 and 4, repackage these messages, with images and quasi-personal text and share with their own networks.

Figure 5 provides an example of quarantine language coaching and planning by $\mathrm{R}+\mathrm{F}$ upline consultants to be used by downline consultants. These tip sheets promote the same evasive language suggestions such as 'especially now' (line 10), 'right now' (14) and clues about the context of the pandemic (line 11: "keep your eyes off the news" and 13: "working from home") without mentioning COVID-19 directly. 
VIRTUAL EVENTS

1 "Hey Mel!! How are you hanging in there, lady? This is crazy. I have been thinking of you. I know

2 you have been keeping $R F$ in the back of your mind, and with so much uncertainty, I wanted to

3 touch base to see if you would like to learn more... or minimally needed a distraction from the

4 news! Tonight we are having a fun Zoom event to share how $\boldsymbol{R}+\boldsymbol{F}$ was born in a recession and how

5 we want to be a huge blessing to our communities during this time. No pressure, but would love

6 your feedback if you have time!"

MOMMY SURVIVAL KIT

7 "Hey mama!! OH.MY.GOSH...did you ever think we were going to be quarantined and

8 homeschooling our kids? This is bananas. I am sure you need some guilt-free pampering, so I am

9 sending you a little "Mommy Survival Kit" to have a spa night at home on me. Every girl needs

10 some pampering, especially now! Thankful for you...enjoy! Xo"”

FINANCE TALK

11 'Hey Julie! Like me, I'm sure you can't keep your eyes off the news...this is crazy. Between the

12 stock market, unemployment climbing, and a possible shut down of the entire economy, I can't

13 tell you how thankful I am for Rodan + Fields. Working from home has been such a blessing for

14 me, and certainly is right now. We only own about 7\% of our category, have a huge innovation

15 coming this year and the launch of Japan. Might you be interested in diversifying your income

16 stream? I would love to chat."

Fig. $5 \mathrm{R}+\mathrm{F}$ independent consultant communication to team of consultants in private Facebook group (March 23, 2020)

Other consultants are more explicit in their references. For instance, in Figure 6 we see how the consultant invokes the COVID-19 economic fallout by asking, "Did you know you could create your own stimulus? Every. Single. Month!" " (lines 16-17). Recontextualized in this post, 'stimulus' not only evokes COVID-19, but suggests an easy income and similar payments. Use of 'stimulus' thus allows the consultant to simultaneously comply with the letter of $\mathrm{R}+\mathrm{F}$ 's directives ('stimulus' is not prohibited) while invoking COVID-19 and making indirect claims about potential earnings. And like the consultants in Figures 3 and 4, this consultant seems to violate $\mathrm{R}+\mathrm{F}$ Policies and Procedures guidelines as she makes claims about her

\footnotetext{
${ }^{4}$ The word 'stimulus' generally refers to anything that stimulates activity or a response; within economics, it refers to targeted fiscal or monetary policy intended to elicit an economic response (e.g., increased spending) within the private sector. In recent months, stimulus has come to serve as a shorthand to refer to the federal government checks of approximately $\$ 1,200$ sent to all adult (non-dependent) U.S. taxpayers who earned less than $\$ 99,000$ as individuals in the prior year.
} 


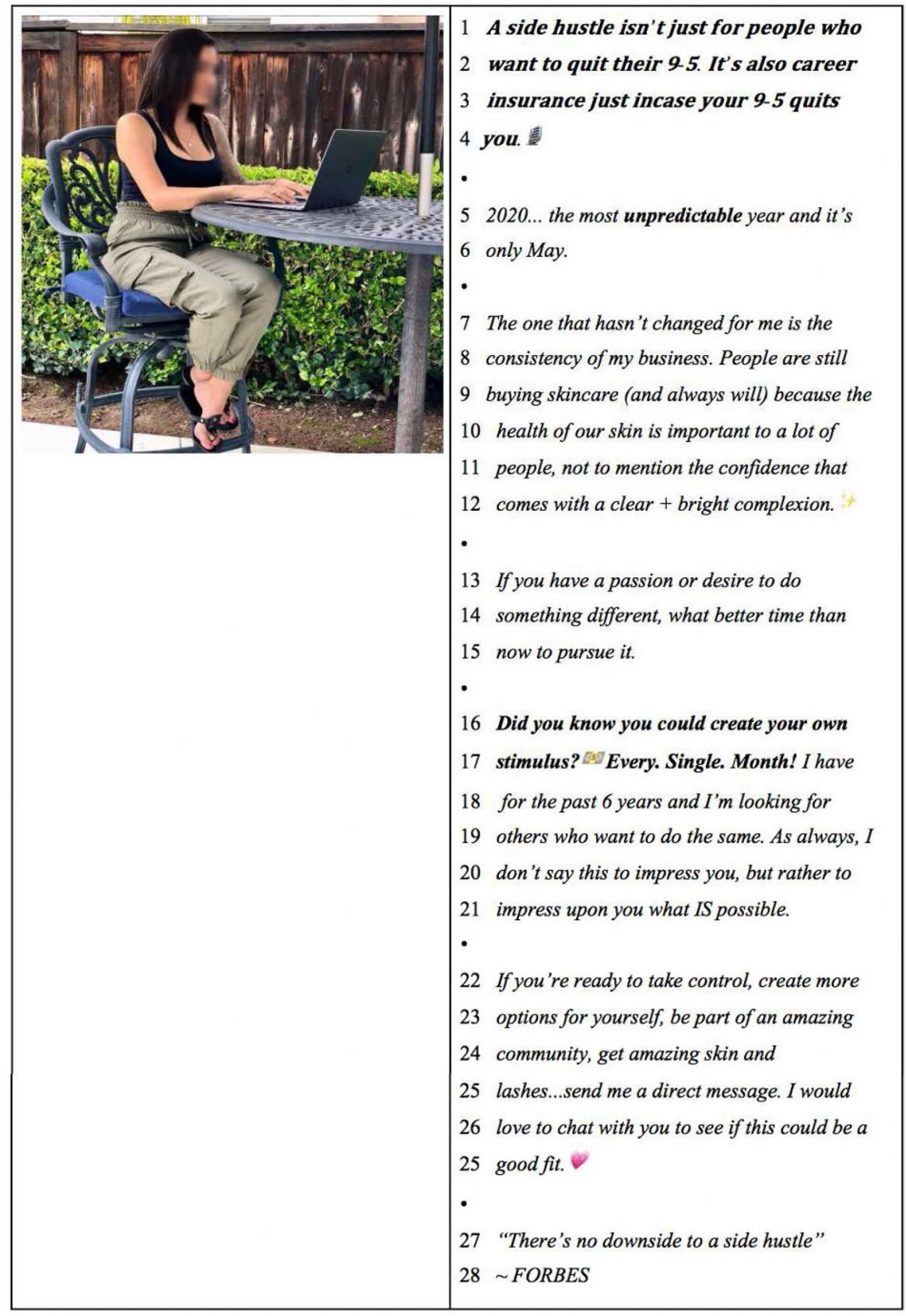

Fig. 6 Instagram post by $\mathrm{R}+\mathrm{F}$ independent consultant (May 1, 2020) 
own earnings (lines 17-18: "I have for the past 6 years!") without providing required disclosures.

Other consultants are less explicit, but still manage to invoke COVID-19 in technically compliant ways. For instance, the post from "Magic Sands Beach" (Figure 7) notes that "We are unfortunately going through tough times and many are struggling to understand and process all the changes we are currently undergoing." (lines 1-4). The references to 'tough times' (1) and 'changes' (3) are vague, but when paired with the left-side image of the empty beach, suggest (pleasant) social distancing. Furthermore, the author references her own (comfortable) home isolation: "I am at ease in the comfort of my home and with my boys..." (7). Taken together, the image of an empty beach and references to "tough times" and home isolation artfully and compliantly situate the pitch within a COVID-19 context.

The author appeals to readers' emotional vulnerability during the COVID-19 pandemic through the use of deictics, here the collective plural pronoun 'we' (lines 1 and 3). This pronoun allows the storyteller to position herself within the story of the COVID-19 "tough times" as with the reader. Use of "us'/"we' throughout consultants' posts renders the fear and uncertainty of the pandemic shared, and thus decreases social distance, making the consultant more personal and relatable to the viewer/reader, who is presumed hesitant about joining the business. She concludes by mentioning the 'wonderful things of the R\&F' world (12-13), suggesting that the business provides positive opportunities in otherwise uneasy times.

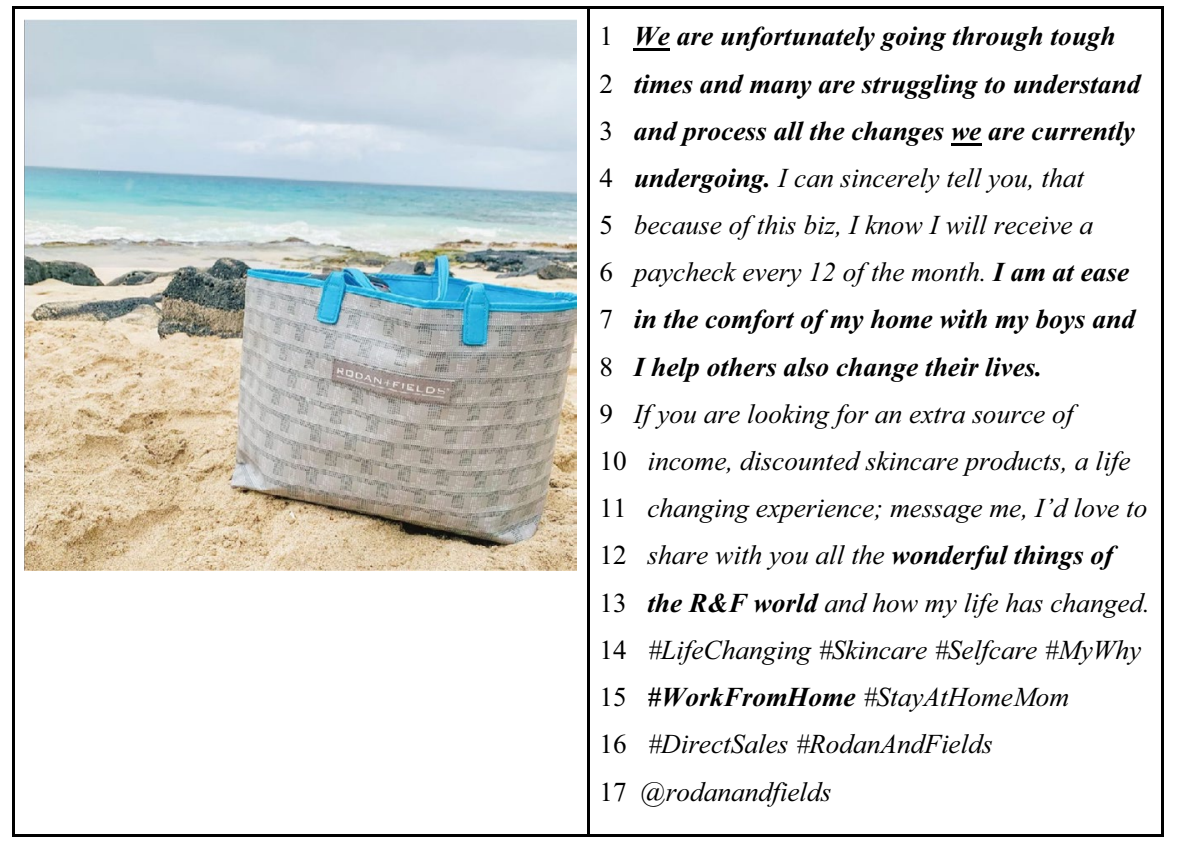

Fig. 7 Instagram post by $\mathrm{R}+\mathrm{F}$ independent consultant (April 25, 2020) 


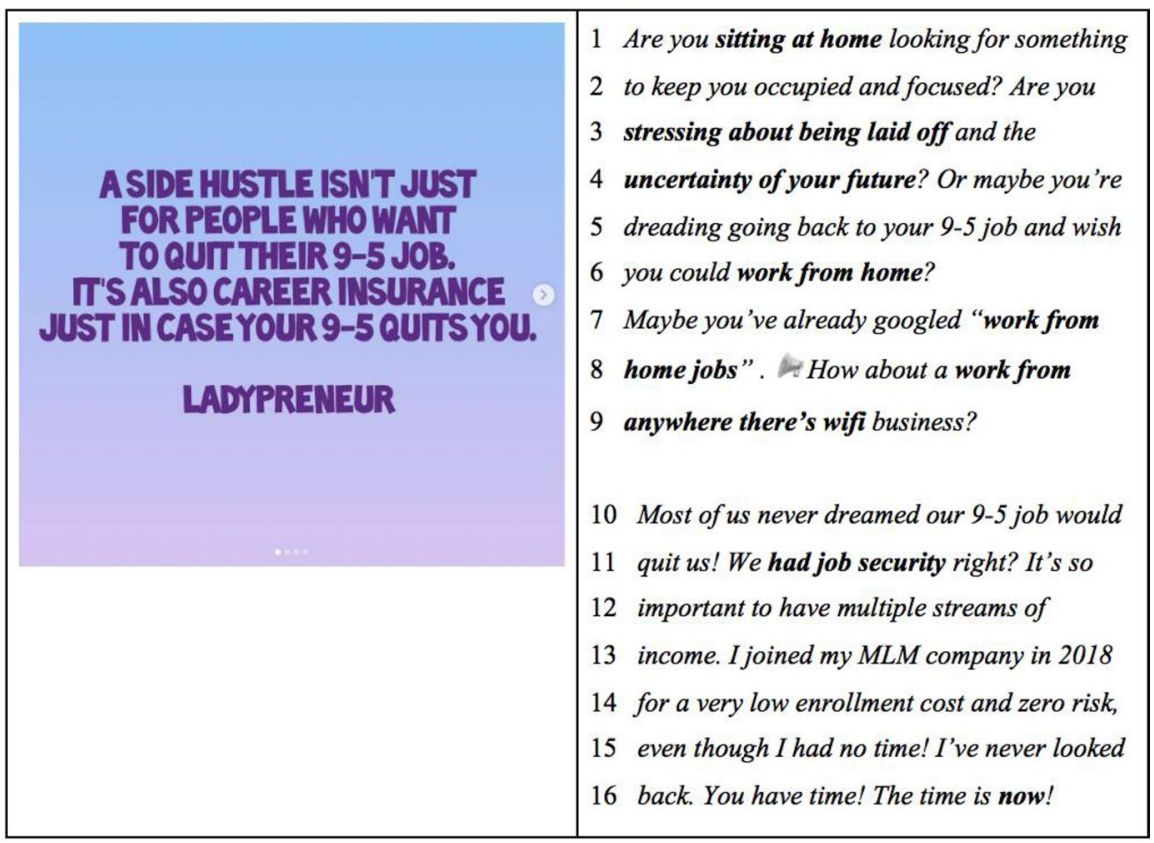

Fig. 8 Instagram post by $\mathrm{R}+\mathrm{F}$ independent consultant (April 18, 2020)

Figure 8 likewise situates the reader in a COVID-19 'now' by listing widely shared emotional, social and economic experiences during the pandemic. These include "sitting at home" (line 1), "stressing about being laid off" (3) and "uncertainty" about the future (4). The author mentions "work from home" (7-8) and then alludes to the appeal of a business opportunity in which individuals can "work from anywhere there's wifi" (8-9). 'Work from home' was a relatively frequently used $\mathrm{R}+\mathrm{F}$ recruitment pitch pre-COVID, but the opportunity to "work from home / anywhere" has been re-entextualized here to reflect the present situation in which many Americans are un/under-employed or working from home in an effort to social distance. The author of Fig. 8 references a prior (pre-COVID-19) situation in which readers "had job security" (11). After explaining her (easy) entry, the author returns to the present and concludes, "The time is now!" (16). The "now' here is of course a time of economic insecurity in the fallout of the pandemic.

To examine the extent to which consultants shifted behavior in light of the $\mathrm{R}+\mathrm{F}$ April compliance directive, we analyzed consultant posts in the ten days prior and ten days following the letter for uses of phrases that potentially invoke COVID-19, but not listed as non-compliant in the $\mathrm{R}+\mathrm{F}$ letters. As evident in Table 2, consultants decreased their use of these terms and hashtags overall, with roughly $37 \%$ of posts using these COVID-19-suggestive words and hashtags prior to the letter, and $22 \%$ ten days following. Nevertheless, such practices continued to appear in more than a thousand posts during the ten-day period following the letter. 
Table 2 Phrases that were not listed explicitly by the $\mathrm{R}+\mathrm{F}$ but potentially reference COVID-19 (The words and phrases reported in the table without hashtags returned 0 results when searched as hashtags.)

\begin{tabular}{|c|c|c|c|}
\hline Phrase & $\begin{array}{l}\text { Number of occurrences ten days } \\
\text { prior to } R+F \text { letter (out of } 5392 \\
\text { posts) }\end{array}$ & $\begin{array}{l}\text { Number of occurrences ten days } \\
\text { following } R+F \text { letter (out of } 6131 \\
\text { posts) }\end{array}$ & Change \\
\hline These times & 16 & 5 & -11 \\
\hline These days & 65 & 58 & -7 \\
\hline Times like these & 8 & 3 & -5 \\
\hline Right now & 376 & 332 & -44 \\
\hline Now more than ever & 30 & 13 & -17 \\
\hline Plan B & 112 & 33 & -79 \\
\hline \#planb & 106 & 50 & -56 \\
\hline Side hustle & 28 & 17 & -11 \\
\hline \#sidehustle & 91 & 72 & -19 \\
\hline Side gig & 25 & 18 & -7 \\
\hline \#sidegig & 65 & 43 & -22 \\
\hline Stimulus check & 19 & 2 & -17 \\
\hline \#stimuluscheck & 6 & 0 & -6 \\
\hline work from home & 46 & 22 & -24 \\
\hline \#workfromhome & 287 & 199 & -88 \\
\hline Uncertain & 98 & 29 & -69 \\
\hline Uncertainty & 46 & 14 & -32 \\
\hline Cocoon & 9 & 27 & +18 \\
\hline Virtual & 236 & 174 & -62 \\
\hline \#virtual & 84 & 65 & -19 \\
\hline Additional income & 25 & 21 & -4 \\
\hline \#additionalincome & 6 & 2 & -4 \\
\hline Extra income & 51 & 36 & -15 \\
\hline \#extra income & 75 & 37 & -38 \\
\hline Work from anywhere & 16 & 11 & -5 \\
\hline \#workfromanywhere & 81 & 46 & -35 \\
\hline Total & 2007 & 1329 & -678 \\
\hline
\end{tabular}

\section{Discussion and conclusion}

This paper set out to address three questions: (1) what federal language policies regulate the marketing of wellness or cosmetic products? (2) how do MLM businesses implement these language policies? and (3) how do individual contractors enact and subvert these language policies? We consider each in turn below.

With respect to the first question, we found that wellness and cosmetic products are regulated by multiple federal agencies, including the FTC and the FDA. The language policies issued by the agencies restrict both the types of claims that MLMs can make and how these claims can be made. The focus of directives issued by these agencies—namely, the FTC — tends to be on earnings claims. Turning to the second 
question, analysis of formal communication between $\mathrm{R}+\mathrm{F}$ corporate offices and its consultants, and informal communication between consultants and their social media followers reveals that the MLM company promotes compliance with FTC regulations in their formal communication with consultants. For instance, their letter to consultants was quickly issued and specific with respect to listing non-compliant language. However, there is no evidence of enforcement of these directives, and abundant evidence that flagrantly non-compliant hashtags and phrases continue to be widely used. ${ }^{5}$

In considering the third question, we find that consultants varied widely with respect to their enactment of these language policies with some consultants mirroring corporate compliance messages in their own private training groups. Concomitantly, both before and after the warning letters, other $\mathrm{R}+\mathrm{F}$ contractors referenced COVID-19 contexts, either implicitly or explicitly. Some did this through what we characterize as flagrant violations (e.g., including '\#recessionproof' in their social media post); others used contextualization cues, deictics and tools of re-entextualization together with imagery to invoke COVID-19 but simultaneously comply with federal and corporate language policy through use of phrases such as 'these days' or 'right now'.

Previous work suggests that hashtags, in addition to categorizing and organizing information, creatively "perform other communicative functions" (Wikström, 2014: p. 127). Our analysis indicates that the hashtags used by $R+F$ consultants should be viewed as creative tools for entextualization in that their dynamic, interactive functions are appropriated by users for tactic, recurring purposes of meaning-making in and across social media (Zappavigna, 2015). One appropriation of hashtags by users is "the exploitation of background knowledge" (Wikström, 2014: 149) in which meaning is construed through shared understanding of the subject. In this case, mutual understanding of the COVID-19 context and its difficulties is exploited by $\mathrm{R}+\mathrm{F}$ consultants as they re-entextualize pre-pandemic hashtags (e.g., '\#workfromhome') to construct a relationship between the hashtag and the pandemic (Zappavigna, 2015). The purposes and affordances of social media are dynamic; therefore, users' communicative manipulations must be documented and analyzed in order to explain how they navigate ever-changing social media environments. Here we see, for instance, how 'work from home' has taken up new meanings-once invoking a cushy benefit, now more often suggesting a pandemic reality or survival strategy.

More broadly, we suggest the tiered structure of MLM companies permits independent contractors to evade federal language policy to seek profit. The hierarchical structure of $\mathrm{R}+\mathrm{F}$ allows the corporate office to issue broad directives that emphasize compliance with the federal language policy; yet autonomous, individual contractors remain largely free to use non-compliant language, disregarding directives with few or no repercussions. The linguistic process of entextualization as well as other discursive and multi-media strategies allows other consultants to technically comply and simultaneously subvert these language policies.

\footnotetext{
5 As of nine months after they were posted, all but one of the examples examined in the findings section were still published on Instagram with the original, COVID-19-invoking language.
} 
Findings also have implications for public life. For consumers, these data highlight the ways in which MLM consultants use language and text in ways that subvert their overtly stated intent (e.g., helping others financially) and use messages of friendship and solidarity to exploit the present COVID-19 context for monetary gain. MLMs have long walked a thin line between (legally) selling a product and (illegally) promoting a pyramid scheme. COVID-19 provides a rich fertile ground for consultants to continue to walk this line in increasingly nuanced ways. The disproportionate economic and social impact of COVID-19 on lower-income individuals has been widely noted (e.g., Cornelissen, 2020). We cannot help but worry that the sophisticated and aggressive marketing techniques by MLMs targeting both already and newly vulnerable individuals have the potential to further exacerbate existing U.S. wealth and income gaps.

For the field of language policy, these findings point to the benefit of close analysis of discourse (Hult, 2010) in order to better understand how language policies are variably enacted across time and space. We illustrated how widely used discourse analysis constructs or tools (e.g., deictics, entextualization) provide insight into the creative techniques in which individuals manipulate and combine a wide variety of texts in ways that can meet the letter of the language policy law but simultaneously evade it for potential profit. As our lives are increasingly dominated by online interactions and interpersonal connections mediated by social media, we suggest that attention to how language policy is enacted and subverted in such domains will continue to be productive and critical.

\section{Appendix 1: April 24, 2020 FTC warning letter to $R+F$}

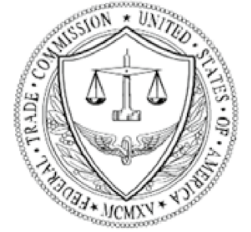

April 24, 2020

Via Electronic Mail
UNITED STATES OF AMERICA

Federal Trade Commission

WASHINGTON, D.C. 20580

Rodan \& Fields, LLC

c/o Jennifer Chaloemtiarana, Chief Legal Officer

60 Spear Street, Suite 600

San Francisco, California 94105 


\section{Warning regarding earnings claims related to coronavirus disease 2019 (COVID-19)}

\section{Dear Ms. Chaloemtiarana,}

FTC staff has reviewed social media posts made by Rodan \& Fields, LLC ("Rodan + Fields") business opportunity participants or representatives that unlawfully misrepresent that consumers who become Rodan + Fields business opportunity participants are likely to earn substantial income. This letter is to provide you with information about laws and regulations enforced by the Federal Trade Commission ("FTC") that may bear upon your business activities, including the activities of your business opportunity participants and representatives.

Some examples of earnings claims made by your business opportunity participants or representatives include:

- "RODAN and FIELDS is always open for business even during quarantine! I've been working from home for over 3 years now and still making money when other people aren't ! Isn't it about time you found out what it is I do and how this company really works ?... \#workfromhome \#financialfreedom."

- "We all need something to fall back on when our Plan A crumbles. For many, many people right now, the Plan A is no longer providing. Given that we are all at home trying to manage this new normal ... Let's chat and get all your questions answered and start getting that Plan B up and running ... bringing in that EXTRA INCOME!... \#extraincome... \#financialfreedom." The text accompanied an image with the text "no risk," "no experience needed," and "can be profitable immediately."

- "During an uncertain time like this, one thing I am grateful for is residual income from my home based business. If you're struggling, and could use an extra few hundred dollars a month, why not give this a try... \#residualincome." The image accompanying the post states, "I have spots available on my team!!! If you want to make an extra $\$ 200, \$ 500$, or $\$ 1000$ a month, message me!"

Representations about a business opportunity, including earnings claims, violate Section 5 of the FTC Act, 15 U.S.C. $§ 41$ et seq., if they are false, misleading, or unsubstantiated and material to consumers. Express and implied earnings claims must be truthful and non-misleading to avoid being deceptive, which means that claims about the potential to achieve a wealthy lifestyle, career-level income, or significant income are false or misleading if business opportunity participants generally do not achieve such results. Even truthful testimonials from participants who do earn significant income or more will likely be misleading unless the advertising also makes clear the amount earned or lost by most participants. Your business opportunity participants and representatives must immediately cease making all express and implied earnings claims that would be false or misleading to current or prospective participants.

You are responsible for the claims of your business opportunity participants and representatives. As the FTC stated in the January 2019 Business Guidance 
Concerning Multi-Level Marketing, the compensation structure of a Multi-Level Marketing entity ("MLM") may create incentives for its participants to make certain representations to current or prospective participants. "As a consequence, an MLM should (1) direct its participants not to make false, misleading, or unsubstantiated representations and (2) monitor its participants so they don't make false, misleading, or unsubstantiated representations."

You are advised to review all claims relating to your business opportunity and immediately cease, and require your business opportunity participants and representatives to cease, making claims that are not supported by the evidence or substantiation described above.

Within 48 h, please send reply via email to COVID-19-Task-Force@ftc.gov describing the specific actions you have taken to address the FTC's concerns. If you have any questions regarding compliance with the FTC Act, please contact us at COVID-19-Task- Force@ftc.gov.

Sincerely,

Federal Trade Commission Staff

\section{Appendix 2: April 25, $2020 \mathrm{R}+\mathrm{F}$ corporate communication to consultants}

RODAN+FIELDS

SHOP SKINCARE

Dear Consultant,

First, our thoughts and well wishes are with you and your families during this difficult time. We hope you are staying safe and well.

Given the impact of COVID-19 and its effect on the global economic environment, this is a sensitive time in our channel. It is imperative now more than ever that we all carefully follow the compliance policies set forth in the $\mathrm{R}+\mathrm{F}$ Policies and Procedures (P\&Ps) to protect Rodan + Fields and your individual businesses.

\section{In addition to following the P\&Ps, it is required that you do not link challenges created by the COVID-19 pandemic and/or economic situation in any way to the $\mathbf{R}+\mathbf{F}$ business opportunity in any of your communications on or off social media}

Specifically, when discussing the $\mathrm{R}+\mathrm{F}$ business opportunity, below are words you must avoid in your communications and will be deemed non-compliant. Some examples include, but are not limited to:

- Coronavirus

- COVID-19

- Quarantine

- Shutdown 
- Social distancing

- Shelter in place

- Pandemic

- Epidemic

- Unemployment

- Recession

- Uncertain times

In addition, please avoid the use of hashtags to circumvent the guidelines outlined above, such as \#quarantine or \#shelterinplace. It is also mandatory that you avoid the use of any hashtags that represent non-typical income earnings, as these continue to be deemed non-compliant. These include, but are not limited to:

- \#financialfreedom

- \#residualincome

- \#timefreedom

- \#careerlevelincome

- \#debtfree

- \#passiveincome

- \#retired

- \#retiredmyspouse

- \#millionairemom

- \#sitbackandearncash

Per our P\&Ps, Rodan + Fields does not tolerate non-compliant/non-typical or misleading income claims. We have a dedicated Compliance team in place, as well as a robust monitoring system, to proactively track, monitor and enforce income and lifestyle claims that may appear in social media posts, videos, blogs, websites, etc. There is, and will continue to be, consequences in place for Consultants who violate our P\&Ps, which includes improper use of earnings and income claims. Please note that any statement or claim making promises of guaranteed or potential income that are not in line with that of the typical or average Consultant, is considered misleading and a violation of Section 6d of our P\&Ps. Please see the Income Disclosure Statement for more information about what is considered typical.

Please proactively review your materials and remove any and all misleading income claims or references to the COVID-19 situation that you may have inadvertently made in accordance with the $\mathrm{R}+\mathrm{F}$ Policies and Procedures or the policies outlined above. Failure to do so will result in consequences to your business. 


\title{
Be sure to check out next week's The Insider Scoop for tips and best practices on sharing the $R+F$ business opportunity.
}

Please direct any questions or concerns to compliance@ rodanandfields.com.

Thank you in advance for avoiding any future improper claims of earnings or earning potential. We appreciate your partnership and efforts in protecting your $\mathrm{R}+\mathrm{F}$ business.

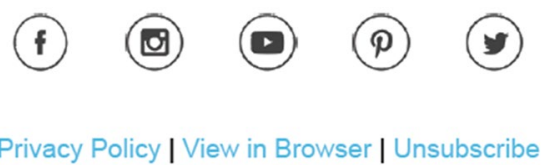

\author{
This email was sent to sabrina.fluegel@hotmail.com by \\ (C2020 Rodan \& Fields, LLC. All Rights Reserved. \\ 60 Spear Street, Suite 600 | San Francisco | CA | 94105
}

\section{References}

Androutsopoulos, J. (2014). Moments of sharing: Entextualization and linguistic repertoires in social networking. Journal of Pragmatics, 73, 4-18.

Angouri, J. (2013). The multilingual reality of the multinational workplace: Language policy and language use. Journal of Multilingual and Multicultural Development, 34(6), 564-581

Asymkos, S. (2020). Popular MLM businesses are leaving young women broke and friendless. Cashay. https://www.cashay.com/mlm-businesses-leave-young-women-broke-friendless-155931120.html

Atkinson, J. M., \& Drew, P. (1979). Order in court: The organization of verbal interaction in judicial settings. Macmillan.

Bauman, R., \& Briggs, C. L. (1990). Poetics and performance as critical perspectives on language and social life. Annual Review of Anthropology, 19, 59-88.

Ben-Rafael, E., Shohamy, E., Hasan Amara, M., \& Trumper-Hecht, N. (2006). Linguistic landscape as symbolic construction of the public space: The case of Israel. International Journal of Multilingualism, 3(1), 7-30

Cassels Johnson, D., Stephens, C., Johnston Nelson, J., \& Johnson, E. J. (2018). Violating lau: Sheltered English instruction programs and equal educational opportunity. Journal of Education Policy, 33(4), 488-509

Cole, D. (2020). Why did it take a pandemic to show how much unpaid work women do? The New York times. https://www.nytimes.com/2020/06/26/opinion/inequality-gender-women-unpaid-work.html? auth $=\operatorname{login}$-google 1 tap \&login=google 1 tap

Cornelissen, A. H. (2020). A triple pandemic? The economic impacts of COVID-19 disproportionately affect black and hispanic households. Joint Center for Housing Studies of Harvard University. https://www.jchs.harvard.edu/blog/a-triple-pandemic-the-economic-impacts-of-covid-19-disproport ionately-affect-black-and-hispanic-households

Chen, A. H., Youdelman, M. K., \& Brooks, J. (2007). The legal framework for language access in healthcare settings: Title VI and beyond. Journal of General Internal Medicine, 22, 362-367

Direct Selling Association. (2020). Research overview: Direct selling in the United States: 2019 industry overview. https://www.dsa.org/statistics-insights/overview

Evans, S., \& Green, C. (2001). Language in post-colonial Hong Kong: The roles of English and Chinese in the public and private sectors. English World-Wide, 22(2), 247-268 
Ehrenreich, S. (2009). English as a Lingua Franca in multinational corporations-Exploring business communities of practice. In A. Mauranen \& E. Ranta (Eds.), English as a Lingua Franca: Studies and findings. (pp. 126-151). Cambridge Scholars Press.

Fair Packaging and Labeling Act (FP\&L Act) (1967). https://www.ftc.gov/enforcement/statutes/fairpackaging-and-labeling-act

Federal Food, Drug, and Cosmetic Act (FD\&C Act) (2018). https://www.fda.gov/regulatory-information/ laws-enforced-fda/federal-food-drug-and-cosmetic-act-fdc-act

Farah, B., \& Higby, M. (2001). E-Commerce and privacy: Conflict and opportunity. Journal of Education for Business, 76(6), 303-307

Federal Trade Commission (2020). FTC sends warning letters to multi-level marketers regarding health and earnings claims they or their participants are making related to Coronavirus. https://www.ftc. gov/news-events/press-releases/2020/04/ftc-sends-warning-letters-multi-level-marketers-regar ding-health

Federal Trade Commission (2019). Multi-level marketing businesses and pyramid schemes. https://www. consumer.ftc.gov/articles/0065-multi-level-marketing-businesses-and-pyramid-schemes

Federal Trade Commission (2018). Business Guidance Concerning Multi-Level Marketing. https://www. ftc.gov/tips-advice/business-center/guidance/business-guidance-concerning-multi-level-marketing

Federal Trade Commission Act (2006). https://www.ftc.gov/enforcement/statutes/federal-trade-commi ssion-act

FitzPatrick, R. (2005). The Myth of “income opportunity” in multi-level marketing. Pyramid Scheme Alert.

Flora, L. (2020). 'Some people got toilet paper, I got hyaluronic acid': Skin-care panic buying is real. https://www.glossy.co/beauty/some-people-got-toilet-paper-i-got-hyaluronic-acid-skin-care-panicbuying-is-real?fbclid=IwAR0FzchAb6VGFtgfiB1qsGCsLTK8GjJ5ojSmHAT7HsoBG06tbRT0K UW9MoY

Giannoulakis, S., \& Tsapatsoulis, N. (2016). Evaluating the descriptive power of Instagram Hashtags. Journal of Innovation in Digital Ecosystems, 3(2), 114-129

Gonçalves, K. (2020). Managing people with language: language policy, planning and practice in multilingual blue-collar workplaces. Language Policy, 19, 327-338

Gressin, S. (2020). FTC letters target more unproven MLM health and earnings claims. In Federal trade commission: Consumer information. https://www.consumer.ftc.gov/blog/2020/06/ftc-letters-targetmore-unproven-mlm-health-and-earnings-claims

Gressin, S. (2019). FTC alleges Neora, formerly known as Nerium, operates an illegal pyramid scheme. In Federal trade commission. https://www.ftc.gov/news-events/blogs/business-blog/2019/11/ftcalleges-neora-formerly-known-nerium-operates-illegal

Gumperz, J. J. (1992). Contextualization and understanding. Rethinking Context: Language as an Interactive Phenomenon, 11, 229-252

Gumperz, J. J., \& Cook-Gumperz, J. (1982). Interethnic communication in committee negotiations. In J. J. Gumperz (Ed.), Language and social identity. (pp. 145-162). Cambridge University Press.

Gumperz, J. J. (1982). Discourse strategies. Cambridge University Press.

Heritage, J. (1985). Recent developments in conversation analysis. Socio Linguistics, 15, 1-18

Hill, P., \& Zyl, S. V. (2002). English and multilingualism in the South African engineering workplace. World Englishes, 21(1), 23-35

Holm, A. E., O'Rourke, B., \& Danson, M. (2020). "Employers could use us, but they don't”: Voices from blue-collar workplaces in a northern periphery. Language Policy, 19, 389-416

Holmes, J. (2012). Discourse in the workplace. In K. Hyland \& B. Paltridge (Eds.), Continuum companion to discourse analysis. (pp. 185-198). Continuum.

Hult, F. M. (2010). Analysis of language policy discourses across the scales of space and time. International Journal of the Sociology of Language, 202, 7-24

Kelly, P., \& Rowland, H. (2000). Ethical and online privacy issues in electronic commerce. Business Horizons, 43(3), 3

Johnson, D. C. (2011). Critical discourse analysis and the ethnography of language policy. Critical Discourse Studies, 8(4), 267-279

Jones, R. H. (2009). Action and text in the digital age. Journal of Applied Linguistics, 6, 283-302.

King, K. A., \& Bigelow, M. (2019). The politics of language education policy implementation: Minnesota (not so) nice? In T. Ricento (Ed.), Language and politics in the U.S. and Canada (pp. 192211). Cambridge University Press. 
King, K. A., \& Bigelow, M. (2018). The language policy of placement tests for newcomer english learners. Educational Policy, 32(7), 936-968

King, K. A. \& De Fina, A. (2010). Language policy and Latina immigrants: An analysis of personal experience and identity in interview talk. Applied Linguistics, 31(5), 623-650.

Katz, L. F., \& Krueger, A. B. (2019). The rise and nature of alternative work arrangements in the United States, 1995-2015. ILR Review, 72(2), 382-416

King, K. A., \& Mackey, A. (2016). Research methodology in second language studies: Trends, concerns, and new directions. Modern Language Journal, 100, 209-227.

Lederer, M. (1979). Blue-collar jobs for women. Dutton.

Martin-Jones, M. (2015). Classroom Discourse Analysis as a Lense on Language-in-Education Policy Processes. In F. M. Hult \& D. C. Johnson (Eds.), Research methods in language policy and planning: A Practical guide (pp. 95-106). Wiley and Sons.

Orendorff, A. (2020). Coronavirus ecommerce opportunities, data \& strategies: Online shopping in the age of COVID-19 [Updated]. Common Thread Collective. https://commonthreadco.com/blogs/ coachs-corner/coronavirus-ecommerce\#coronavirus-ecommerce-data

Partnoy, F. (2014). Is herbalife a pyramid scheme?. The Atlantic. https://www.theatlantic.com/magazine/ archive/2014/06/wall-streets-6-billion-mystery/361624/

Pullin Stark, P. (2009). No joke-This is serious! Power, solidarity and humour in business English as a Lingua Franca (BELF) meetings. In A. Mauranen \& E. Ranta (Eds.), English as a Lingua Franca: studies and findings. (pp. 153-177). Cambridge Scholars Press.

Punti, G., \& King, K. A. (2013). A perfect storm for undocumented youth? Multi-level marketing, discourses of advancement and language policy. In V. Ramanathan (Ed.), Language policies and (dis) citizenship: Rights, access, pedagogies (pp. 92-115). Clevedon: Multilingual Matters.

Rattner, N. (2020). As coronavirus restrictions drag on, Americans shift online spending from stockpiling to entertainment. NBC News. https://www.cnbc.com/2020/04/19/coronavirus-what-americans-arebuying-online-while-in-quarantine.html

Ricento, T. K. (1996). Language policy in the United states. In M. Herriman \& B. Burnaby (Eds.), Language policy in English-dominant countries: Six case studies. (pp. 122-150). Multilingual Matters.

Richards, L. (2019). How MLMs - multilevel marketing schemes — are hurting female friendships. Chicago Tribune. https://www.chicagotribune.com/business/ct-biz-mlm-female-friendship-costs20190122-story.html

Rodan + Fields (2021a). Press room. https://www.rodanandfields.com/press-room

Rodan + Fields. (2021b). Meet our founders. https://www.rodanandfields.com/our-story/meet-our-found ers

Rodan + Fields (2020a). Consultant policies and procedures (Version 15.1). United States. https://www. rodanandfields.com/images/archives/policies_and_procedures.pdf

Rodan + Fields (2020b). U.S. business kit comparison guide. https://www.rodanandfields.com/assets/us/ business-kit-comparison-guide.pdf

Rodan + Fields (2019). 2019 Income disclosure statement. United States. https://www.rodanandfields. com/assets/us/income-disclosure-statement.pdf

Rodan + Fields (2017). Enrollment kits USA. https://www.rodanandfields.com/images/archives/Enrol lment_Kits_USA.pdf

Radford, M., Tarapani, K. \& Jones, M. (2020). Product talk, make an impact with mini regimens. Rodan + Fields.

Silverstein, M. (1992). The indeterminacy of contextualization: When is enough enough. In P. Auer \& A. Di Luzio (Eds.), The contextualization of language (pp. 55-75). John Benjamins.

South Dakota Consumer Protection (2020). Multi-level marketing vs pyramid schemes. https://consumer. sd.gov/fastfacts/marketing.aspx

Schnurr, S., \& Zayts, O. (2017). Language and culture at work. Routledge.

Taylor, J. (2011). The case (for and) against multi-level marketing: the complete guide to understanding the flaws - and proving and countering the effects - of endless chain "opportunity" recruitment, or product-based pyramid schemes. Consumer Awareness Institute.

Thurlow, C. (Ed.). (2020). The business of words. Wordsmiths, linguists and other language workers. Routledge.

Tiffany, K. (2020). The internet is starting to turn on MLMs. The Atlantic. https://www.theatlantic.com/ technology/archive/2020/12/tiktok-bans-multilevel-marketing-mlm/617422/ 
U.S. Department of Transportation: Federal Aviation Administration. (2017). Advisory circular: faa english language standard for an FAA certificate issued under 14 CFR Parts 61, 63, 65, and 107 (6028B). https://www.faa.gov/documentLibrary/media/Advisory_Circular/AC_60-28B.pdf

U.S. Food and Drug Administration. (2018a). Is it a cosmetic, a drug, or both? (or is it soap?). https:// www.fda.gov/cosmetics/cosmetics-laws-regulations/it-cosmetic-drug-or-both-or-it-soap

U.S. Food and Drug Administration. (2018b). FDA authority over cosmetics: How cosmetics are not FDA-approved, but are FDA-regulated. https://www.fda.gov/cosmetics/cosmetics-laws-regulations/ fda-authority-over-cosmetics-how-cosmetics-are-not-fda-approved-are-fda-regulated

U.S. Food and Drug Administration. (2017). Cosmetics labeling guide. https:/www.fda.gov/cosmetics/ cosmetics-labeling-regulations/cosmetics-labeling-guide

Wikström, P. (2014). \#srynotfunny: Communicative functions of hashtags on Twitter. SKY Journal of Linguistics, 27, 127-152

Wodak, R., \& Savski, K. (2018). Critical discourse-ethnographic approaches to language policy. The Oxford handbook of language policy and planning, 93-112.

Wodak, R. (2011). Complex texts: Analysing, understanding, explaining and interpreting meanings. Discourse Studies, 13(5), 623-633

Wortham, S., \& Reyes, A. (2015). Discourse analysis beyond the speech event. New York: Routledge.

Zappavigna, M. (2015). Searchable talk: The linguistic functions of hashtags. Social Semiotics, 25(3), 274-291

Zappavigna, M. (2012). Discourse of twitter and social media: how we use language to create affiliation on the web. Bloomsbury.

Publisher's Note Springer Nature remains neutral with regard to jurisdictional claims in published maps and institutional affiliations.

Sabrina Fluegel is a Ph.D. Student in the Hispanic Linguistics program in the Department of Spanish and Portuguese Studies, University of Minnesota, MN. Her research interests include language policy, language use, identity, and ideology with recent work focusing on the discourse analysis of online discussions surrounding "trending" moments in society.

Kendall King is a Professor of Second Language Education in the Department of Curriculum and Instruction, University of Minnesota, USA. Her current research focuses on language policy and second language education with particular attention to the experiences of minoritized student populations. 